\title{
TE்VŲ, AUGINANČIŲ VAIKUS, TURINČIUS AUTIZMO SINDROMĄ, NUOMONE் APIE DANTŲ ĖDUONIES PROFILAKTIKOS GALIMYBES
}

\author{
Rita Juchnevičienė, Daiva Mačiulienė, Vaidilė Juškytė \\ Kauno kolegijos Medicinos fakultetas
}

Raktažodžiai: autizmo sindromas, ugdymas, dantų èduonies profilaktika.

\begin{abstract}
Santrauka
Autizmas yra vienas iš sudètingiausių raidos sutrikimų. Autizmas yra patologinis žmogaus uždarumas, kuris apima socialinį ir emocinį nesupratimą, bendravimo sunkumą, mąstymo ir elgesio nelankstumą. Siekiant autizmo negalią turinčiu žmonių neatskirti nuo visuomenès reikètų skirti daugiau dèmesio ju prisitaikymui. Taikant stuktūruoto interviu metodą, atliktas tyrimas, kuriame dalyvavo 7 vaiku tèvai, auginantys autizmo sindromą turinčius vaikus. Apklausos metu buvo siekiama sužinoti tėvų nuomonę apie dantų èduonies profilaktikos galimybes. Visi tyrime dalyvavę informantai teigè, jog pas burnos priežiūros specialistą reikètų vaiką pratinti apsilankyti profilaktiškai kuo anksčiau, siekiant geriausiu burnos higienos rezultatu. Kaip ankstyvoji autizmo diagnostika nepaprastai svarbi tolesnei vaiko raidai, taip ir ankstyvasis supažindinimas su dantų èduonies profilaktikos galimybėmis yra labai svarbus siekiant išvengti dantų èduonies.
\end{abstract}

\section{Ivadas}

Pasaulyje autizmo tema yra gana plačiai žinoma, tačiau Lietuvoje apie tai dar nèra daug kalbama. Jungtinių Valstijų vyriausybė teigia, kad pastaraisiais metais susirgimų autizmu padaugèjo nuo 10 iki 17 procentų, kadangi sergamumas autizmu sparčiai padidèjo, išaugo mokslininkų susidomèjimas ir atliekamų tyrimų skaičius [3]. Autizmas - vienas iš sudètingiausių raidos sutrikimų, kurio patogenezė dar nèra plačiai žinoma. Autizmo simptomai nulemia raidos nukrypimus, kurie apima daugeli psichikos funkcionavimo sričių. Būdingi visą gyvenimą trunkantys socialinio bendravimo, komunikacijos ir elgesio sutrikimai [5]. Siekiant autizmo sutrikimą turinčių žmonių neatskirti nuo visuomenès reikètu skirti daugiau dèmesio integruojant juos i visuomenę. Kiekvienam vaikui su autizmo sindromu reikia ieškoti tinkamo būdo mokytis, išlaikyti dėmesį ar reaguoti i pasikeitimus. Atsižvelgiant ị autistų suvokimą, mąstymą, pojūčius, galima rasti elgesio sunkumų sprendimo būdus. Tèvai, auginantys vaikus, turinčius autizmo sutrikimą, susiduria su daugybe psichologinių, pedagoginių ir socialinių sunkumų, todèl ypač svarbu ieškoti galimybių palengvinti šių pacientų apsilankymus pas burnos sveikatos priežiūros specialistus - odontologus, burnos higienistus. Pasitelkiant ịvairias terapijas bei programas galima palengvinti bendravimo ir elgesio sunkumus.

Tyrimo tikslas: atskleisti vaikų, turinčių autizmo sindromą, dantų èduonies profilaktikos galimybes.

\section{Tyrimo objektas ir metodologija}

Ištirtos 7 tèvų, auginančių vaikus, turinčius autizmo sindromą, nuomonès apie dantų èduonies profilaktikos galimybes. Vaikų amžius nuo 3 iki 9 metų. Duomenys buvo renkami apklausinèjant struktūrinio interviu būdu, atlikta duomenu analizè. Visiems tirtiems vaikams diagnozuotas autizmas arba autizmo spektro sutrikimas. Pasirinktas struktūrinis interviu, nes tokiu būdu galima išsamiau sužinoti tèvų nuomonę apie jų vaikų elgesio ypatumus bei dantu èduonies profilaktikos galimybę. Prieš pradedant kiekvieną interviu respondentai buvo informuojami apie jų anonimiškumą, konfidencialumą ir tyrimo duomenu pristatymą apibendrintai.

Autizmo sindromas. Etiologija ir paplitimas. Šiuo metu autizmas laikomas nespecifiniu sutrikimu, kurị sukelia ịvairūs kenksmingi organiniai, biologiniai ir genetiniai veiksniai. Pagrindiniai autizmo požymius sukeliantys mechanizmai - smegenų struktūros disfunkcija ir biocheminių procesų sutrikimas smegenyse.

Pagal tarptautinę ligų klasifikaciją TLK-10, autizmas priskiriamas ịvairiapusių raidos sutrikimų grupei.

Autizmas [2] yra raidos sutrikimas, pasireiškiantis per pirmuosius tris gyvenimo metus, paveikiantis smegenų sričių, atsakingų už bendravimo ir socialinių igūdžių vystymąsi [4]. Patogenezė ir etiologija tiksliai nėra žinomos. Manoma, kad ypač svarbus yra genetinis komponentas, nes 
homozigotiniai dvyniai turi didesnę riziką abu būti autistai nei heterozigotiniai ar gimę pavieniui broliai ir sesès. Chromosomų pakitimai, neurologinès ligos taip pat yra dažnas susijęs veiksnys.

Vis didejjantis ịvairių sričių specialistų, mokslininkų bei visuomenès susidomejjimas šia sritimi lemia, kad autizmo atvejų nustatoma vis daugiau, geriau atpažįstami sutrikimo simptomai ir tiksliau diagnozuojami. Lietuvoje autizmo paplitimas tarp $7-16$ metu vaikų nustatytas 11,8 iš 10000 . Amerikoje 1 iš 88 vaikų turi autizmo spektro sutrikimą [6].

Pagrindiniai autizmo požymiai - sutrikęs socialinis bendravimas, kalbos raidos ir komunikacijos problemos, netipiškas, keistas elgesys, vaizduotès bei laiko suvokimo problemos. Vienas pirmujų autizmo požymių - bet kokio aplinkinių prisilietimo atstūmimas [1].

Taigi vaikų, turinčių autizmo požymių, smegenys visą informaciją apdoroja kitaip negu normaliai besivystančiu vaikų, todèl jiems sunku bendrauti su kitais žmonèmis. Dèl šios priežasties vaikai, turintys autizmo sutrikimą, atsiriboja nuo aplinkos, sunkiai formuoja socialinị elgesic, yra neramūs bei patiria naujos aplinkos baimę, pastebi atskiras detales, bet nepajègia jų susieti.

Pagrindiniai autizmo sutrikimą turinčių vaikų ugdymo metodai. Jei autizmas ar autizmo spektro raidos sutrikimas negydomas, daugeliui jị turinčių vaikų nepavyksta igyti pakankamai socialinių igūdžių, t.y. jie gali neišmokti kalbèti ir deramai elgtis. Šiuo metu galima ieškoti galimybiu pasitelkti ìvairias efektyvias terapijas bei programas, tokias kaip ABBA, TEACCH (simbolių), Son-Rise ir kt., kuriomis galima palengvinti kasdienių ịūdžių tobulinimą, aplinkos pažinimą, kalbos, socialinius igūdžius [2]. Siekiant kuo geresnès autizmo sutrikimo prognozès, svarbu kuo anksčiau pradèti teikti jiems efektyvią pagalbą, gydyti ir ugdyti. Išanalizavus ABBA, Son - Rise ir TEACCH ugdymo programų principus ir atlikus struktūrinio interviu analizę, galima daryti prielaidą, jog naudojantis TEACCH ugdymo programos principais imanoma pasiekti teigiamu rezultatu dirbant su vaikais, turinčiais autizmo sindromą. Pagrindinè šio metodo ideja - ugdymo proceso metu mokyti vaikus autistus naudotis paveiksliukais (nuotraukomis). Visi nurodymai pateikiami vizualiai. Instrukcijos pateikiamos labai aiškiai ir nuosekliai ,iš viršaus ị apačią; iš kairès ị dešinę“. Vaikams, turintiems sunkaus laipsnio autizmo sindromą, taikoma paprastesnè simbolių sistema, tai - PECS (Picture Exchange Communication System) sistema, kurią sudaro elementarūs paveikslèliai.

Pasitelkus šios programos principus ir iš anksto aptarus su tèvais vaikų elgesio ypatumus, galima padaryti individualių apsilankymų planus, asmenines programas, pagal galimybes ịtraukiant sudètingesnes ir ịvairesnes procedūras, atliekamas odontologijos kabinete.

Tyrimo rezultatų analizė. Sturktūruoto interviu klausimų eiliškumas buvo sudarytas pagal klausimų svarbą. Pirmieji klausimai buvo ịvadiniai, kuriais sužinojome, ar apskritai tèvai buvo ką nors girdèję apie autizmo sindromą prieš jų vaikui diagnozuojant ši sutrikimą. Kitais klausimais svarbu buvo sužinoti apie aplinkybes per pirmuosius vizitus pas burnos priežiūros specialistus, apsilankymų svarbą siekiant išvengti burnos ligų, žinias apie ugdymo programas, taip pat individualių burnos higienos priemonių parinkimą ir racionalios mitybos įtaka dantų èduoniui.

\section{Rezultatų aptarimas}

Požiūris ir žinios apie autizmo sindromą. Pasiteiravus informantų apie jų požiūrị i i autizmo sindromą prieš vaikui ji nustatant, jie teigè jog: ,toks sutrikimas yra kažkas baisaus“; „kai dar nežinojau, kas yra autizmas, tai man siejosi su agresija, su protiniu atsilikimu, lingavimu“. Informantuc žinios parodè, jog autizmo sindromu jie domèjosi: , jau kai specialistai nustatė diagnozę, buvau pakankamai prisiskaičius apie šị sutrikimą“; ,,studijuodama esu girdèjus apie ši sutrikimą. Vèliau dirbau su visokias negalias turinčiais vaikais, taip pat ir su autizmo sutrikimą turinčiais“; ,dar prieš mano vaikui gimstant padèjome rinkti informaciją apie ši sutrikimą bendradarbei, kuri jau turejo vaiką su autizmo sutrikimu $<\ldots>$ gimus maniškiui po trejų metų pastebejau, kad kažkas negerai $<\ldots>$ pradejjau sekti ir ieškoti, kas tai galètų būti“. Tačiau kai kurie informantai teigè, jog žinių apie autizmo sutrikimą trūko: ,informacijos labai trūko apie ši sutrikimą, kai jau jos ieškojome".

Sunkumai ugdant asmens higienos igūdžius. Analizuojant burnos higienos sunkumus informantai pastebi, jog: ,pradèjus naudoti dantų pastą su skoniu vaikas labiau leidžiasi valytis dantis“, sunkumų iškyla skalaujant burną ir kai vaikas priešinasi valymuisi:,,bandom mokintis skalauti burną, bet kol kas dar sunkiai išeina.“; „skalauti dar nemoka, bet kai sakau atsigert vandens ir išspjaut, jam tai puikiai pavyksta“; „valytis dantis sunkiai pavyksta. Pats vaikas šepetėlį laiko rankose, bando kažką daryti, bet dantų neišsivalo. Todèl išvalome dantis kartu su teečiu, vienas laiko, kitas valo, nes kitaip jokios burnos higienos priežiūros neturètume“. Informantai pastebi, jog ilgai ir kruopščiai išvalyti dantų nepavyksta, tačiau stengiasi valytis: „nemėgsta, kai labai ilgai valomès dantis su dantu šepetėliu, todèl procedūra turi būti labai greita“; ,reikia ieškoti naujų būdų, kaip jam pateikti dantų valymąsi iš naujo <..> susiduriame su skalavimo problema“; „blogai valomès, bet stengiamès valytis. Nepasiduoda valymui, priešinasi $<\ldots>$ bet dantuc pastos išskalavus neišspjauna, o nuryja“; ,maždaug nuo 4 metų vaikas laiko dantų šepetèlị ir bando juo valytis dantis 
pats, kadangi labai gerai neišsivalo, aš pervalau. Jis nèra patenkintas, kai valau ten, kur jis nenori, bet leidžiasi. Bandèm naudoti dantų siūlą, bet kelis kartus, kai buvau nupirkus, ištraukdavo visą iš dèžutès ir žaisdavo“.

Pirmasis apsilankymas pas burnos priežiūros specialistą. Informantai teigia, jog pirmieji apsilankymai dažniausiai būna traumos ar būtino apsilankymo metu, todèl vaikai patiria skaudžias patirtis: ,dèl dantų traumos $<\ldots>$ vaikas nesileido, odontologas davè tabletę, nuo kurios buvo pridujęs, vaikas baltų chalatų bijo“; ,„pirmą kartą buvome beveik trejų metų, kai <..> susitrenkè dantį“; ,vaikas išsigando nepažįstamų žmonių, jis nieko nesileido, kad būtų daroma“; „buvo daroma narkozė“. Kiti informantai teigia, jog: „nebuvom ịejję ị odontologinị kabinetą, nes per daug stresinè situacija, todèl dantis preliminariai apžiūrèjo koridoriuje“;pirmą kartą „apsilankème profilaktiškai“; „pirmus kartus praleisdavo koridoriuje prie odontologinio kabineto gulèdama $<\ldots>$ po kiek laiko gulèdavo jau kabinete. Dar vèliau mes ịejome i kabinetą, apvaikščiojome ji““; ,tik vieną kartą, kai ejome profilaktiškai“. Turejjus pirmąją blogą patirti odontologijos kabinete sunku pasitikèti burnos priežiūros specialistais ir apskritai daktarais, todèl reikia iš naujo kurti santykị, svarbu specialistui būti užtikrintam savo darbu ir nesinervinti:,,reikejjo atstatyti vaiko pasitikejjimą burnos priežiūros specialistais $<\ldots>$ iš naujo pratinomès prie odontologinés kèdės bei visos ịrangos $<\ldots>$ po kelių metų $<\ldots>$ nebe taip bijojo, apsižiūrèjo ir stsisèdo i kèdę“; „,vaikas ramiai atsisèdo ị kèdę ir išsižiojo. Specialistė buvo rami, nesinervino, mokèjo bendrauti su vaiku.“ Informantai teigia, jog vaikams turi būti specialiai paruošta aplinka, kuri jų negąsdintų: „bijojo triukšmą keliančių garsų“.

Išanalizavus interviu atskleista, jog tik maža dalis tėvų veda vaikus profilaktiškai pasitikrinti pas burnos priežiūros specialistą, dažniausiai lankosi esant traumai ar kitu sunkiu atveju. Autistas vaikas, turèjęs skaudžią pirmają patirtị odontologijos kabinete, stengiasi ten daugiau nebesugrižti. Informantai pastebėjo, jog specialistams pavyksta susikalbèti su autistu vaiku, kai jie yra ramūs, užtikrinti savo darbu bei aplinka paruošta pirmiesiems vizitams.

Apsilankymo pas burnos priežiūros specialistus svarba siekiant išvengti burnos ligų. Apklausinejus informantus sužinojome, jog nauji dalykai sukelia nemalonius pojūčius bei stresines situacijas: „kas nauja - sukelia stresą, kiekvienas apsilankymas $<\ldots>$ nèra paprastas $<\ldots>$ labiausiai gąsdina nauja aplinka, ypač garsai, kuriems yra jautrus“. Informantai teigia, jog sveikatos specialisto apranga turi įtakos vizito sėkmei: ,patyrème nemalonių procedūrų, kurias atliko daktarai, jie vilkejjo baltus chalatus, todèl nuo to laiko jis nemėgsta jų. Kelia isterijas, kai pama- to baltą chalatą $<\ldots>$ persirengè ị mèlyną, vaikui pasidarè ramiau ir leidosi apžiūrimas“. Kiti informantai teigia, jog daktaro pažinimas suteikia pacientui pasitikejjimą: „mano vaikas labai atsirenka žmones <...> turi kitas žmogus igyti pasitikejjimą, kad leistų ką nors daryti su juo“; „,bet žmogaus pažinimas, igytas pasitikèjimas daktaru, palengvintų apsilankymą“; „tai priklauso pas kokį odontologą jis paklius. Mano vaikas iš karto atskiria, ar specialistas bijo, jaučia stresą ir nerimą". Tyrimo dalyviai akcentavo, jog kuo anksčiau pradejus lankytis pas burnos priežiūros specialistus, tuo lengviau bus ateityje rasti kontaktą:,,kuo anksčiau pradejjus pratinti vaiką prie odontologinio kabineto, tuo lengviau būtų su juo dirbti“; , ,net neịsivaizduoju, kad taip paprastai pirmą kartą atejjus ị odontologinę kèdę mano vaikas išsižiotų“; , ,reikia pratinti vaiką prie odontologinio kabineto“. Kelių informantų manymu, žinojimas apie ankstyvojo dantų èduonies atsiradimo priežastis padètų jo išvengti: „besilaukdamos vaiko mamos ateina pasitikrinti burnos sveikatos, turètų būti ịspejjamos apie vaiko dantų priežiūrą, buteliuko èduonị. Mano atveju tai būtų padèję"; „besilaukdamos vaiko mamos $<\ldots>$ turètų būti informuojamos apie dantų priežiūrą, buteliuko èduonị, apie pirmuosius apsilankymus pas odontologus/burnos higienistus vien tam, kad vaikas jau būtų matęs tokią aplinką ir vèliau jam tai nebūtų naujové“.

Autizmu sergančių vaikų naudojamos individaulios burnos higienos priemonès. Paklausus informantų apie individualios burnos higienos priemonių naudojimą visi teigia, jog dažniausiai naudoja: „dantų šepetèli ir dantų pastą“; retai kas naudoja ,liežuvio grandiklį“. Keli informantai teigia, jog dantų pastos skonis, kvapas ir spalva turi įtakos dantų valymui: „būtinai baltą, beskonę ir bekvapę dantų pastą, kurią tiktai vieną pripažįsta“. Informantai teigia, jog: ,valomės ryte ir vakare, laikomès kasdieninès dienotvarkès".

Autistų individualios burnos higienos galimybès, pritaikant TEACCH ugdymo programą. Tyrimo dalyviai akcentavo, jog kuo anksčiau pradejjus dirbti su TEACCH programa, tuo jiems lengviau buvo pasiekti geru rezultatų: „einame ị priekị, padareme pažangą“; „yra dalykų, kuriuos pradejome daryti, ko anksčiau nedarydavome“; „programa tikrai veiksminga, žinoma norètųsi greitesnių rezultatu, bet judame savu tempu“; „TEACCH programą naudojame $<\ldots>$ kai tik autizmo sindromas buvo diagnozuotas“; „simbolių sistema visame kame padeda mums prisitaikyti prie naujovių, tiek naujų vietų lankymo, tiek metų laikų prisitaikymo“; „TEACCH programa naudojamès, namuose turime didelę knygą, pripildytą kortelių ir simbolių, be kurios jau neịsivaizduojame mūsų gyvenimo"; „simbolių sistema ir filmuota medžiaga padeda prisitaikyti 
prie kasdieniu permainų“. Buvo minima, kad kreipiantis specialias tarnybas, kai kurie informantai niekur nebuvo informuoti apie tinkamas ugdymo programas ir jų panaudojimą, kurios būtų palengvinusios jų kasdienius rūpesčius: „esame girdèję $<\ldots>$ kai ieškojome informacijos apie ugdymo būdus buvo pasiūlyta šita programa naudotis, tačiau informacijos, kur korteles įsigyti, kaip pagal jas dirbti nebuvo pasakyta“; „dabar pradèjome susipažinti, kas būtent tai per programa“; „„̌inome iš dalies“. Kai kurie interviu dalyviu minèjo, jog namuose dirbti su ugdymo programomis sekasi sunkiai: „,namuose sunkiai sekasi“; „,namie mes ja nesinaudojame“. Tačiau visi informantai sutinka, jog draugystė ir ryšys su burnos priežiūros specialistu palengvintų apsilankymus: „motyvuotų draugystė su burnos higienistu/odontologu, pas kurị norètų nueiti“.

TEACCH ugdymo programa padeda tobuleti, prisitaikyti prie permainų daugeliui autistų vaikų. Ypač svarbus ryšys tarp specialisto ir paciento, kuris palengvina apsilankymus pas burnos priežūros specialistus.

Autizmu sergančių vaikụ tẻvų požiūris ị mitybos ịtaką èduoniui. Tyrimo dalyviai pritare, jog mityba turi įtakos dantų èduoniui: „tinkama mityba turi teigiamos įtakos“. Dauguma interviu dalyvavusių informantų teigè, jog dienos bėgyje užkandžiauja, nors kai kurie vaikai yra išrankūs maistui, kuriam kartais prireikia specialaus paruošimo, kad būtų suvalgytas: „,vaikas nèra labai valgus, nors užkandžiauja gan dažnai sausainius ar vaisius“; ,,mėgsta daugiau sūresnị ar beskonị maistą. Mègsta užkandžiauti < ...> mègsta beveik kiekvieną kąsni paskalauti vandeniu“; „daugiau mėgstame sausainius, sausus užkandžius, duoną, obuolius, kuriuos dienos metu gan dažnai valgome $<\ldots>$ kai kurioms daržovėms ir vaisiams reikia tam tikro paruošimo“; „labai išrankus maistui $<\ldots>$ vaisius valgo tiktai nulupus žievelę, braškes tiktai iš mūsų daržo“; ,valgo visokius nevalgomus dalykus, tokius, kaip smèlį, žemes, žaislų detales ir t.t."; „per dieną labai dažnai užkandžiauja pasiimdamas baranką, duoniuką < ..> nenustoja valgyt visą dieną“. Kai kurie tèvai teigia, jog vaikas nèra išrankus maistui: „viską valgome“; „valgo beveik viską". Tyrimo dalyviai akcentavo, jog saldumynų stengiasi vengti, tačiau ne visada pavyksta jų atsisakyti: „stengiamès vengti saldumynų, labai retai valgome šokoladą, nes žinome, kad negalima“; ,saldumynus labai ribojame“; ,saldaus maisto praktiškai nevalgome, išskyrus glaistytą sūrelį“; „naktimis saldžių gèrimų negeriame, nes žinome, kad negalima“; „kartais norint nuraminti vaiką duodame kokio nors saldaus maisto“; „stengiamès vengti saldumynų, bet po saldainị per dieną tikrai suvalgo". Interviu dalyviai pastebejo, jog jų vaikams išsivystè buteliuko ėduonis, dèl netinkamos mitybos, kai kuriems iš informantų trūko žinių apie buteliuko eduonies atsiradimo priežastis, sužinoję stengèsi išvengti burnos ligų keliančių veiksnių: „,iki dvejų metų pamaitinus savo pienu, nevalydavome dantų, todèl išsivystè buteliuko èduonis”; „nežinodavau, kad vaikams negalima duoti saldžiai gerti prieš miegą. Todèl po kurio laiko jo dantys pradejjo gesti, išsivystè buteliuko èduonis $<\ldots>$ sužinojus stengèmès nebeduoti nieko saldaus prieš miegą“; „buvo išsivystęs buteliuko eduonis“; „gerdavom dažnai pirktinių sulčių, dèl kurių, manau, ir turèjom buteliuko edduonic“; „dabar prieš miegą visada išsivalome dantis".

Apibendrinant mitybos reikšmę dantų ėduonies profilaktikai galime teigti, jog būtina informuoti tèvus apie buteliuko èduonies atsiradimo priežastis. Tai dar kartą parodo apsilankymų svarbą vos pradejjus dygti pirmiesiems pieniniams dantims.

\section{Išvados}

1. Atlikus mokslinès literatūros analizę atskleista dèsningai dažnejjantys autizmo sindromo diagnozavimo atvejai visame pasaulyje. Taip pat išanalizavus mokslinès literatūros šaltinius galima daryti išvadą, jog autizmo požymiai taikant tinkamas ugdymo ir reabilitacijos formas mažeja, autizmo sutrikimą turintys vaikai gali būti sèkmingai ugdomi, todèl kiekvienu atveju aktualu ieškoti efektyvių individualiai taikomų ugdymo metodų.

2. Pagrindinè ėduonies išsivystymo priežastis yra nepakankama burnos higiena. Atsižvelgiant į autizmo sindromą reikia individualiai pritaikyti burnos priežiūros priemones, nes dantys nèra natūraliai pakankamai apsaugoti nuo ėduonies. Mityba taip pat turi didelę reikšmę èduonies profilaktikoje. Nuo tėvų požiūrio priklauso, kokị maistą valgys mažamečiai. Dažnas kariesogeniškų produktų valgymas sukelia dantų ligą - eduonį. Kaip ankstyvoji autizmo diagnostika nepaprastai svarbi tolesnei vaiko raidai, taip ir ankstyvasis supažindinimas su dantų èduonies profilaktikos galimybėmis yra labai svarbus aspektas siekiant išvengti dantų èduonies.

3. Išanalizavus tyrimo rezultatus galime teigti, jog daugumos pirmi apsilankymai yra tik esant būtinumo situacijai, bet ne profilaktiškai. Tẻvai jaučia informacijos trūkumą apie tinkamą burnos priežiūrą bei ugdymo programas. Autistams vaikams naujos situacijos sukelia stresą, todèl pirmiesiems vizitams turi įtakos tinkamas odontologijos kabineto paruošimas, burnos priežiūros specialisto žinios ir kūno kalba. Taip pat pastebèta, jog turi būti tinkama specialisto apranga (vengti baltos aprangos). Tyrimo metu atskleista, jog specialisto pažinimas vaikui autistui suteikia pasitikèjimo. Tèvų nuomone, TEACCH programa palengvina apsilankymus pas burnos priežiūros specialistus. Autistai yra individualiai unikalūs, todèl nèra tokio gydymo 
metodo, kuris vienodai padètu kiekvienam autistui. Svarbu, kad tèvai dirbtų su specialistais ir kuo anksčiau pradètų teikti efektyvią pagalbą.

\section{Literatūra}

1. Rebecca J. Landa. Diagnosis of Autism Spectrum Disorders in the First 3 Years of Life CME. 2008.

2. DiBattisto MD C. (2011) Autism spectrum disorder. [žiūrèta 201401 24] Prieiga internetu: <www.medmerits.com/index. php/article/autistic_disorders/P13>

3. Pop-Jordanova N., Plasevska-Karanfilska D. (2014) Autism - genetics, electrophysiology and clinicial syndromes.2014;35(1):133-46 [žiūrèta 201403 09] Prieiga internetu: $<$ http://www.ncbi.nlm.nih.gov/pubmed/24802198>;

4. Baio J., 2010 Prevelance of Autism Spectrum Disorder Among Children Aged 8 Years - Autism and Developmental Disabilities Monitoring Network [žiūrèta 201405 13] Prieiga internetu: $<$ http://www.cdc.gov/mmwr/preview/mmwrhtml/ss6302a1. htm?s_cid=ss6302a1_w $>$

5. American Psychiatric Association. Diagnostic and statistical manual of mental disorders. 5th ed. Arlington, 2013 [žiūreta 20140503 ]

Prieiga internetu:

$<$ http://www.dsm5.org/Documents/Autism\%20Spectrum\%20 Disorder\%20Fact\%20Sheet.pdf $>$;

6. Presidential Documents, 2013. Proclamation 8954 of April 1, 2013. World Autism Awareness Day.
REVEAL PARENTS, WHO IS GROWING CHILDREN WITH AUTISM, OPINION ABOUT PROPHYLACTIC POSSIBILITIES OF TEETH DECAY

R. Juchnevičienė, D. Mačiulienė, V. Juškytė

Key words: autism syndrome, education, dental caries prevention.

Summary

Autism is one of the most complicated disorder of development. Autism (autos - self) is pathological human reticence, which includes social and emotional misunderstanding, difficulties of communication, inflexibility in thinking and behavior. Aiming not isolate people with autism from society, should be given more attention to their adaptation.. With help of structured interview method, accomplished research, in witch was taking part seven parents growing children with autism. This disorder is challenge for parents of children with autism, so mouth hygienist should help knowing about peculiarities of such disorders. All informant of the research said that child should be habituated make visits to mouth care specialist as earlier as possible, seeking to reach best results of mouth hygiene. Regular visits to mouth hygienist can help to avoid mouth diseases.

Correspondence to: daiva.maciuliene@go.kauko.lt

Gauta 2014-06-20

\section{KVIEČIAME PRENUMERUOTI "SVEIKATOS MOKSLŲ" ŽURNALĄ 2015 METAIS!}

Žurnalas "Sveikatos mokslai" (Index Copernicus, EBSCO host (Academic Search Complete), Gale (Academic OneFile), ProQuest (Ulrich's, Summon), Australia (ERA) 2012 Journal List (ERA ID 34962) skirtas visų specialybiu gydytojams, slaugytojams ir kitiems specialistams, spausdina mokslinius straipsnius lietuvių, anglų ir rusų kalbomis. Reikalavimai straipsniams atitinka mokslo leidiniams keliamus reikalavimus.

\section{Žurnalas kioskuose neparduodamas.}

Žurnalą, kuris leidžiamas kartą per du mėnesius, galima užsiprenumeruoti visuose Lietuvos pašto skyriuose, taip pat internetu: www.post.lt

Prenumeratos kaina nesikeičia: visiems metams - 120 Lt/34,75 EUR, šešiems mẻnesiams - 60 Lt/17,37 EUR, keturiems mėnesiams - 40 Lt/11,58 EUR, dviem mènesiams - 20 Lt/5,79 EUR. Prenumeratos kodas: 5348.

Žurnalo autoriams straipsnių spausdinimas mokamas. 